\title{
Theological debate among Buddhist sects in Indonesia
}

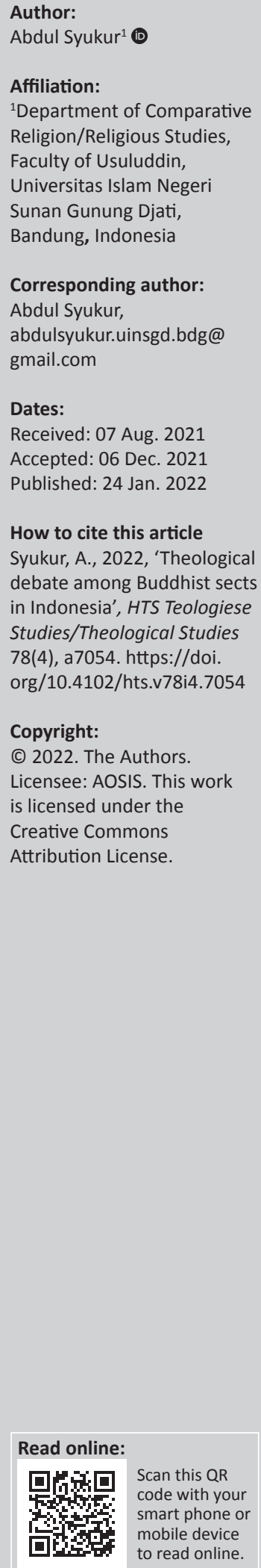

Indonesian Buddhism has many sects such as Theravada, Mahayana, Buddhayana, Tantrayana, Maitreya, Tridharma, Kasogatan, Nichiren and so on. These sects historically come from the same source, the Buddha's teachings, but now they have differences in terms of doctrines and practices. This article analyses the differences with regard to their doctrines and beliefs in relation to the concept of God as required by the Indonesian Constitution. The discussion focuses on the debate among three sects, namely, Buddhayana, Theravada and Mahayana, about the name and nature of God and sources of doctrines on which they rely. The research was conducted in Jakarta and Bogor which focused mainly on the organisation of Nichiren Shoshu Indonesia (NSI). The data were collected through book and document study, observations and interviews with NSI followers. Additional data was performed in Bandung in 2019 by interviewing Buddhayana and Theravada adherents. The research finds that Buddhayana was successful in formulating the concept of God based on an old manuscript, Sang Hyang Kamahayanikan, so that Buddhism has met constitutional requirements and eventually has been accommodated as one of the official religions. However, it has been challenged by both Theravada and Nichiren, which rely on other sources of doctrines.

Contribution: This article contributes to the theological discourse among Buddhist sects, which are rarely discussed by Buddhist scholars. Buddhist adherents in Indonesia not only have political responsibility as required by the Constitution, but also have a socio-ethical responsibility in terms of religious tolerance both within and outside other religions.

Keywords: Religious sect; Buddhism; Monotheism; Nichiren Syosyu Indonesia; Indonesia.

\section{Introduction}

There are several Buddhist sects in Indonesia today. In fact, it can be said that Indonesia is like a port from which various Buddhist sects anchor, grow and develop. Although each sect claims to be a Buddhist but they have different views on issues related to social, political and cultural issues in Indonesia.

The focus of the research initially was Nichiren Shoshu Indonesia (NSI), one of the organisations of the Nichiren sect originating from Japan. I did this early research for the purpose of completing my dissertation. During fieldwork I came up with something new in my knowledge that is a Japanese term, Namyohorengkeyo, which refers to the concept of God while I realised that Sang Hyang Adi Buddha is the concept of God for Buddhism. On the other hand, I also heard that Theravada has rejected the Buddhayana's concept of Sanghyang Adi Buddha as Buddhist God. This article, therefore, will discuss the Buddhayana, Theravada, Mahayana and NSI views related to the concept of the One Godhead (monotheism) contained in the Pancasila and the Constitution of the Republic of Indonesia.

This article is based on two periods of anthropological research. The first one was carried out by implementing ethnographic observation to understand doctrines and practices of especially Nichiren sect. This was conducted in Jakarta and Bogor where I participated in rituals and preaching and had much discussions about Nichiren. The second research was conducted in Bandung where Buddhayana was first established in Indonesia and Theravada also has many followers. I interviewed people in Vihara Vimaladharma and Vihara Karuna Mukti, who are representations of Buddhayana dan Theravada schools, respectively. 


\section{Buddhist sects in Indonesia}

There is not a definite figure regarding the number of Buddhists in Indonesia, but the results of the population census conducted by the Central Statistics Agency (Badan Pusat Statistik [BPS]) in 2010 show that the number of Buddhists is 1703 254, which is $0.71 \%$ of the total population of Indonesia (i.e. 237641326 inhabitants) (BPS 2010). This number has increased from the results of the $2000 \mathrm{BPS}$ census where the number of Buddhists was 1694682 people, but in terms of percentage it has decreased from $0.84 \%$. The population of Indonesia increased rapidly from 201241999 people in 2000, namely 36399327 people. The latest data of Buddhist number released by the Ministry of Religious Affairs in 2018 show that Buddhism is followed by 2062150 adherents, which means $0.77 \%$ of the total population of 266534836 people and increased to $0.06 \%$ from 2010 census (https://data.kemenag.go.id/ statistik/agama/umat/agama).

Brown (1987) estimated that there were 2.5 million followers of Buddhism until 1987, with a composition of 1 million adhering to the Theravada school, 0.5 million being followers of Buddhayana and the rest being part of other schools. Meanwhile, Suryadinata (ed. 1997) stated that according to the 1990 population census the number of Buddhists was 1.8 million or $1 \%$ of Indonesia's population, whereas WALUBI on its website, citing the Bodhi Buddhist Center Indonesia and Kalyanadhammo Press websites, lists the number of Buddhists in various countries in the world, regardless of sect, and states that the number of Buddhists in Indonesia is 5.5 million, which is proportionally $2 \%$ of the entire Indonesian population (Source: https:/ /www.walubi.or.id/).

Previously, Suryadinata, Nurvidya Arifin and Ananta (2003:104) suggested a comparison of the number of Buddhists according to the 1971 and 2000 censuses. According to the 1971 census, the number of Buddhists was 1092314 $(0.92 \%)$, while according to the 2000 census there were 1694682 Buddhists (0.84\%). Although in terms of numbers there is an increase, it has decreased in terms of percentage. This is because of Indonesia's total population figure which increased sharply from 118367850 (1971) to 201241999 (2000). On the other hand, the increase in the number of Buddhists was a result of the policies of the New Order government, which did not recognise Confucianism as a religion in 1979 so that, in Java in particular, all Confucians were categorised as Buddhists on their ID cards and marriage documents (Suryadinata et al. 2003).

The number of Buddhists discussed above is divided into several sects, namely, Theravada, Mahayana, Tantrayana (Vajrayana/Mantrayana), Tridharma, Buddhayana, Kasogatan, Maitreya, Nichiren and others. It can be said that Buddhism in Indonesia represents almost all schools of Buddhism in the world.

Historically, only two major schools were known, namely, Hinayana and Mahayana. However, from these major streams various ideas emerged, which in turn formed groups with distinctive characteristics. Literally 'Hinayana' means 'boat' or 'small vehicle'. This term was given by those who later identified themselves as the 'Mahayana' group which means 'big boat' or 'vehicle'. The word 'Hinayana' has a derogatory meaning as a class that only cares about its own safety, as represented in the life of the monks. With the belief that to attain Nirvana and escape from worldly attachments one has to work on oneself, the monks, as the Mahayana class says, are 'selfish' because they are self-centred.

Because the word 'Hinayana' is considered an expression of contempt from the 'opponent', then as an alternative the group called 'Hinayana' also chooses its own term and prefers to call itself the 'Theravada' group, which means 'the way of the elders'. The term 'Theravada', therefore, implies the belief that the teachings of the Theravada religion originated and practised or passed down by the earlier monks who had a series of ties with the disciples and, indeed, to the Buddha himself. The belief that the teachings have a connection with Sakyamuni Buddha, making Theravada followers believe that Theravada teachings are purer or more original than the teachings or beliefs of other groups so that in the context of religious movements it often gives birth to what is said to be the Orthodoxy movement. Currently, Theravada people in Indonesia are joining the Indonesian Theravada Buddhist Council (MAJUBUTHI) under the auspices of the Indonesian Theravada Sangha (STI), which is heavily influenced by Thailand's Theravada religion.

On the other hand, the word 'Mahayana' which means 'big boat' or 'vehicle' implies the understanding that in Mahayana the path of salvation can not only be reached through the monk's path, but also through worship so that Mahayana can be followed by more people. Mahayana's monkhood rules are also loose. In contrast to the Theravada school that ideologically aspires to achieve enlightenment by one's own efforts, the life goal of the Mahayana school is to achieve enlightenment and become a Bodhisattva, that is, a person who can help others achieve enlightenment. In this case, Mahayana can be equated with the Reformation movement or Protestantism in Christianity. Mahayana people in Indonesia are members of the Indonesian Mahayana Council (MAHASI) and the Indonesian Mahayana Sangha organisation.

Furthermore, with regard to Tantrayana, Dutavira (1985) suggested that historically it originated from Mahayana, but then Tantrayana developed in such a way that in the context of conversation and, especially, the religious practices it showed independent characteristics in which aspects of esotericism became so prominent that it became a separate sect. Kasogatan is one of the Tantrayana subsect, which promotes Buddhism based on Sang Hyang Kamahayanikan text as practised in the period of Majapahit kingdom. Now, with Tibetan Tantrayana school, Zhenfo Zong, Kasogatan formed an organisation of followers named ZFZ KASOGATAN under Sangha Vajrayana Indonesia. 
In the early 20th century, there were efforts to renew the traditions of the Chinese community. This renewal coincided with efforts to revive Buddhism in Indonesia by monk Narada - the Buddhist theosophist and missionary from Sri Lanka. One of the Chinese descendants who was also involved in the effort to arouse Buddhism was Kwee Tek Hoay, the Theosophist activist. The Theosophy movement and Narada's monks tended to the Theravada school so that at first Kwee Tek Hoay was oriented towards Theravada. However, as Brown (2003) said, carrying out the revival of Buddhism by renewing the beliefs and traditions of the ancestral heritage conducted by Kwee Tek Hoay could not release Kwee Tek Hoay from his ethnic background problems, so finally Kwee Tek Hoay founded organisation Sam Kauw Hwe (Organisation of Three Religions). After independence Sam Kauw Hwe changed his name to Tri Dharma (Suryadinata 1997), which became part of the Mahayana school. Thus, it can be said that while Buddhayana seeks to unite the sects within Buddhism, Tri Dharma seeks to maintain traditional Chinese ethnic beliefs that are a combination of three teachings, namely, Confucianism, Taoism and Buddhism.

Sangharakshita (1985) suggested that being a Bodhisattva is the ideal of life in the Mahayana school so that Mahayana is also referred to as Bodhisattvayana and because the purpose of Bodhisattvayana is to attain the highest level of Buddhahood, Bodhisattvayana is identical or often referred to as Buddhayana. However, in the Indonesian context, the term 'Buddhayana' has its own meaning. Etymologically, Buddhayana consists of the words 'Buddha' and 'yana' and thus the meaning of Buddhayana is 'Vehicle of Buddha' or 'Road of Buddha'. Such an understanding is closely related to the fact that in its history Buddhism was divided into three major schools, namely, Hinayana (Theravada), Mahayana and Tantrayana. In accordance with the direction of its development, each of these streams tends to be exclusive.

In the view of the Jinarakkhita, the founding figures of Buddhayana, the differences that exist between the three schools of Buddhism are merely expressions of tradition, while the essence of its own teachings is fixed and the same (Juangari 1995), namely, the teachings originating from Sakyamuni Buddha. Therefore, it is necessary to have a forum to unite the three major schools and the container is nothing but Buddhayana, which literally means 'Buddha Way' or 'Buddha Vehicle'. Furthermore, because Buddhayana saw that the different schools (yana) were actually one in the broader structure of Buddhism, the term 'Buddhayana' was also often identified with the term 'ekayana', which means 'one way'. In the back page of the book Understanding Buddhayana (Dharmavimala 1995), it is said:

Buddhayana is a technical terminology used to refer to and summarize views, schools of teachings, or even the understanding of Buddhism as a whole. Thus [Buddhayana] is equivalent to Buddhism itself ... Besides Buddhayana Ekayana is also known. From this understanding we can clearly see that Buddhayana or Ekayana is not a new sect in any Buddhist environment in the world, including in Indonesia. (p. 174)
Organisationally, Buddhayana consists of the Indonesian Supreme Sangha (Sangha Agung Indonesia [SAGIN]), in which monks assembled from the Theravada Sangha, Mahayana Sangha, Tantrayana Sangha and Bhikuni Sangha, while lay Buddhists gathered in an organisation called Majlis Buddhayana Indonesia (MBI) (Manggala 1994). The SAGIN is a continuation of the Maha Sangha Indonesia. In 1972, the Theravada monks separated themselves from the Indonesian Supreme Sangha and founded the Indonesian Sangha. In 1974, based on the government initiative they reunited and changed the organisation name to SAGIN. But in 1976, the Theravada monks again separated themselves by forming the TheravadaSangha. However, in subsequent developments Buddhayana is not only what is referred to as a 'single container' (Dharmavimala 1995), which is federative. Dharmavimala himself said that in addition to being 'Wadah Tunggal' it turns out that Buddhayana also made its own formulations with regard to the scriptures and rituals (vandana), which are different from the schools contained in them.

Nichiren Shoshu Indonesia is one of the organisations affiliated to the Nichiren sect. Not only NSI is affiliated with the Nichiren Shoshu sect but there are also other organisations, namely, Buddha Dharma Indonesia (BDI). Nichiren Shoshu Indonesia was founded on 28 October 1964 by Senosoenoto, a native Javanese who married a Japanese woman, Keiko Sakurai. Nichiren Shoshu Indonesia formed the organisation Parisadha Buddha Dharma Nichiren Shoshu Indonesia (PBDNSI), while BDI formed the organisation Council for Nichiren Shoshu Buddha Dharma Indonesia (Majelis Nichiren Shoshu Buddha Dharma Indonesia [MNSBDI]).

The Nichiren sect, as represented by the NSI, explained its doctrine not by using terms commonly used by followers of the Theravada, Mahayana, Tantrayana and Buddhayana schools. According to Harvey (1990), Nichiren aimed at reforming the Tendai school, one of the sects of the famous Mahayana sect in China and introduced in Japan by Saicho or Dengyo, by only emphasising the Lotus Sutra as the main scripture, which he considered to be the essence of the teachings of Buddhism. Nichiren regarded himself as a substitute for the founder of T'ien T'ai and as an incarnation of the Bodhisattva mentioned in the text of the Lotus Sutra that he would be the guardian of the teachings of the Lotus Sutra in the last days. The Nichiren sect worshiped Gohonzon. A sacred mandala consists of writing the kanji, which is obtained as a result of Nichiren's enlightenment. Gohonzon is considered to be a representation of the cosmos or the universe and its laws. Suhadi, Chair of the NSI, said that even though it is an object of worship, Gohonzon 'is not a talisman that can give something to people who ask for it' and 'Gohonzon does not give happiness or safety and punishment' to humans because happiness and suffering are determined by human actions. The ritual practice is called the daimoku. The essence of the ritual is the worship of Gohonzon by reading or calling the mantra of Nammyohorengekyo and doing gongyo. Etymologically, the word Nammyohorengekyo 
consists of two words, Nam (Sanskrit) which means 'surrender' and Myohorengekyo (Japanese) which means 'Saddharma Pundarika' or Natural Law. Parita readings are taken from the text of the Lotus Sutra. Gongyo means reading the parita contained in the kyobon, a pocket book that is a guide for NSI followers to carry out rituals. Kyobon itself consists of several parts: hoben-pon, juryo-hon and a collection of prayers. As the holy parita, the hobbies and juryo-hon found in the kyobon are taken from the text of the Lotus Sutra. In addition to the daimoku, gongyo is also performed in death rituals and marriage rituals. Because Gongyo, Gohonzon and Nammyohorengekyo mantra are the core of the ritual, Gohonzon presents the death ceremony and marriage ceremony and reads or mentions Nammyohorengekyo.

\section{Theological debate}

While in other religions the problem of God, who God is and how it relates to humans and the universe become the central teaching in the system of its teachings, the Buddha actually sees the problem as a limiting factor for human liberation from suffering (dukkha). Smith (1985) compared Sakyamuni Buddha with the 'Revolting Saint'. Even though the Buddha took the source of his views from Hinduism, 'overall Buddhism is a reaction to Hindu deviations: a kind of Indian Protestantism'. One of the targets of the reaction carried out by the Buddha was the problem of God, which was conceived in various ways in Hinduism. In the Buddha's view, the existence of various human conceptions of God shows the inability of reason and the human mind to understand the true nature of God. Instead of thinking about God's problems, the Buddha understands and teaches what reality is: humans live in suffering and how to escape suffering.

In the reality of social life there are many conditions that can be considered as suffering: birth, ageing, illness, death, meeting with unfriendly persons, facing unwanted circumstances, not getting what they want, feeling sadness, complaining and so on (Rahula 1985). Previous speculations about God rather than escaping from suffering is analogous to the illustration as follows:

Like a person who is wounded by an arrow that is thickly smeared with poison. When a friend and relative will call a surgeon to cure him, he says, I will not tell to remove this arrow until I know who hurt me, whether he is from the knight caste, brahmana, or pariah ... is he tall or short, black, dark, or light yellow ... does it come from the city, from the village ... is the bow that it uses made of a type of chapa, kodanda, or bamboo ... is the bowstring made of reeds, fibers bamboo, or vein ... is the arrowhead made of wild wood or intentionally planted ... So before he knew all the answers he would die (quoted with a modification from Smith 1985:125).

The absence of the concept of God in Buddhism made some people assume that Buddhism was not a religion. The use of the term 'religion' to Buddhism is inappropriate because Buddhism does not recognise God or Godhead (Horner 1959). On the other hand, Conze (1975) said that even though there is no concept of God in Buddhism there are several teachings that pertain to the attributes of God. In other words, Conze (1975) said that Buddhism does not know God in a personal sense, but what is known in Buddhism is Divinity, so Buddhism can still be classified in the category of religion.

The debate about whether the teachings of the Buddha can be said to be religious or not as mentioned here was also experienced by the people of Indonesia. So far, it is assumed that the basis for recognition of Buddhism as one of the official religions by the Indonesian government is the Presidential Decree No. 1/1965 where in the explanation of the letter it was said that 'The religions embraced by the Indonesian population are Islam, Christianity, Catholicism, Hinduism, Buddhism and Confucianism'. The problem is, what is called 'religion'? This then becomes a challenge for state managers to formulate a definition of 'religion'.

Based on the State Constitution of the Republic of Indonesia, the first and foremost that must be possessed by all citizens is the belief in the God (the One). Ishii (1984) suggested the definition of religion that is held by the Indonesian government, namely, that every religion must have three criteria: the belief in God or the One Godhead, the existence of Prophets and the existence of the Scriptures. In this case, the criterion for 'Prophet' means 'carrier of teachings', while 'Scripture' means 'handbook' which contains teachings. Thus, it is inevitable that Buddhists must follow the State Constitution and adjust themselves to formulating a formula regarding Buddhism that meets the criteria of the definition of religion as proposed by the government.

Regarding the criteria of the 'Prophet' and 'Scripture' it seems that Buddhists have no significant problems. With the understanding that the 'Prophet' is the 'carrier of teachings' and 'Scripture' is 'the handbook', they all agree that Siddhārtha Gautama (Sakyamuni Buddha) is their Prophet and the Tripitaka is their Holy Book. It is different from the problem of God, when Sakyamuni Buddha himself preferred to be quiet when asked about the problem. However, another Sakyamuni Buddha is also a Buddhist.

In the face of the above, political demands at first Buddhayana, which was pioneered by Ashin Jinarakkhita, tried to formulate a concept of God for Buddhism. In their efforts they succeeded in formulating that God in Buddhism was Sang Hyang Adi Buddha. Brown (1987) said that Dhammaviriya, one of Ashin Jinarakkhita's followers, later published an article in 1965 entitled 'The God in Buddhism' in which he put forward a formula about Buddhism that fits the criteria of government as follows (Dhammaviriya 1965):

- God Almighty [Buddhism] is Adi Buddha.

- Prophets [Buddhism] are Gautama Buddha and Bodhisattvas.

- The Scriptures are (1) Tripitaka, (2) Dhammapada (actually still part of the Tripitaka and (3) Sang Hyang Kamayanikan. 
It is said that the term of Adi Buddha or Sang Hyang Adi Buddha as a Godhead concept in Buddhism is taken from ancient text of Sang Hyang Kamahayanikan. Adoration of Adi Buddha can also be found in Nepal (Malalasekara 1984). This can be seen mainly in BH Hodgson's study of religion in Nepal where Adi Buddha is considered the origins of the Buddhas and therefore Adi Buddha is often regarded as God and is often described as a distinctive feature of Buddhism in Nepal. It is further said that, on the one hand, such an identification was a result of the development of Buddhism, especially the Mahayana school, so Buddhism became a religion that is theistic and, on the other hand, this is because of the influence of the teachings of Sivaism. The concept of Adi-Buddha might be the last attempt of Buddhism in Central Asia to compete with Islam by rejecting Islamic teachings. Buddhism seeks to show that even the teachings of monotheism can be found in Buddhism (Eliot 1998; Malalasekara 1984).

It seems that both Ashin Jinarakkhita and his followers are fully aware that in Buddhism there is no concept of God. Sakyamuni Buddha avoids discussion about God because God's essence is infinite and therefore it is impossible to understand the very limited human minds. But even the political demands of the state cannot be responded to because otherwise the existence of Buddhism will be at stake. Therefore, in this case Ashin Jinarakkhita and his friends must inevitably be pragmatic (Brown 1987). In addition, Ashin Jinarakkhita's inclusive ethnic politics enabled the Buddhayana he led to be flexible in looking at sect or sect boundaries so that they were accommodating towards local beliefs and culture. This is evidenced by the acceptance of the Sang Hyang Kamahayanikan manuscript, which speaks Kawi as part of the Scriptures in Buddhism. From the text, Sang Hyang Adi Buddha was born, which was used as the concept of Godhead in Buddhism. Ishii (1984) mentioned that Sang Hyang Adi Buddha as the concept of Godhead in Buddhism was born in May 1965 - four months before the PKI coup 30 September 1965 (G30S/PKI). In an anti-Communist sociopolitical context, Buddhayana's response was very positive so that Buddhists were freed from accusations of atheism or, at least, were not considered PKI sympathisers who were considered to have launched a bloody coup against military power.

Furthermore, in every ritual and religious ceremony the words 'Namo Sang Hyang Adi Buddha' are spoken as an introductory expression. However, because in Buddhism there are also Theravada and Mahayana schools, the introduction to rituals and ceremonies was added with the words 'Namo Tassa Bhagavato Arahato Sammasambuddhasa' and 'Namo Sabbe Boddhisatvayeh Mahasatvayeh'. The success of Buddhayana in formulating the concept of Sang Hyang Adi Buddha as the concept of the Godhead in Buddhism was also followed by the Government Regulation of the Republic of Indonesia No. 21/1975 concerning the oath/pledge of civil servants, Article 4 paragraph (5), which states that the oath used by Buddhists who become civil servants is to take the oath 'for the sake of Sang Hyang Adi Buddha' (Juangari 1995:147).

However, what Ashin Jinarakkhita and his followers had done in the Buddhayana was later questioned by his own Theravada followers. At first they accepted the concept, but later with the visit of monks from Thailand and after several followers of Ashin Jinarakkhita were ordained as monks in Thailand, things changed. The followers of Ashin Jinarakkhita, who had been ordained as monks in Thailand, began to object and reject the concept of the Godhead of Sang Hyang Adi Buddha. In fact, in the end, they took their own path apart from Ashin Jinarakkhita and Buddhayana, they left SAGIN and established their own organisation, namely, the Indonesian Sangha, then the STI.

In their view there is no such thing as 'Sang Hyang Adhi Buddha' as a concept of God in Buddhism. Bhikkhu Narada from Sri Lanka, who had previously visited Indonesia in 1934 and then in 1959 and 1959, was among the Theravada figures who vehemently rejected the concept of God. He wrote to Parvati, Ashin Jinarakkhita's student and secretary, urging him: 'Please, tell your teacher that there is no God in Buddhism' (Juangari 1995).

It is not just a matter of the name 'Sang Hyang Adi Buddha'. Nanang, a Theravada follower, had no problem swearing by the phrase 'for the sake of Sang Hyang Adi Buddha' when he was sworn in as a civil servant (Pegawai Negeri Sipil [PNS]). He also said that in the beginning Buddhayana had good intentions, namely, to unite the schools of Buddhism. But what made him object to Buddhayana was that the concept of Sang Hyang Adi Buddha was taken from the text of Sang Hyang Kamahayanikan, not from the Pali Tripitaka. For him, the text of Sang Hyang Kamahayanikan is a Mahayana text that has been mixed with local beliefs (syncritic). He then says that the Theravada concept of God is found in Udana, VIII, 3 as follows:

Know the monks that something is not born, that is not incarnate, the uncreated, the absolute. How can the monks, if there is no Unborn, Not Incarnate, the Unbirthed, the Absolute, then it will not be possible for us to be free from birth, incarnation, formation, emergence from past causes? But the monks, there is the Unborn, the Unincarnated, the Uncreated, the Absolute, then it is possible to be free from birth, incarnation, formation, emergence from the previous caus. (Brown 1987:115)

The Udana Book is part of the Khuddaka Nikaya contained in the Pali Tripitaka. For Theravada who strictly adhered to the Pali Tripitaka, Sang Hyang Kamahayanikan is not a legitimate source for attracting the law let alone being a source of belief. From the above quotation, it can be seen that the concept of the Godhead in the Theravada school is impersonal and without name. On the contrary, as Suyanto, one of the priests of the Theravada, says, the concept of Sang Hyang Adi Buddha tends to be personal.

Another issue that became an objection was conveyed by Suyanto. He also appreciated Buddhayana's goodwill to 
unite Buddhists. But by accommodating all the schools that exist in Buddhism makes Buddhayana a 'Sadayana' school. As a result, in Buddhayana there are many rituals. He also said that the reason Theravada monks left SAGIN was because there were many violations of principles of nature. For example, the leniency of the monk's rules, namely, it is allowed to have dinner and bring money. He also criticised Ashin Jinarakkhita's appearance and role. For example, they are dressed in Theravada robes but have mustaches and beards, so that their identity as a monk becomes unclear. In addition, Ashin Jinarakkhita's role in SAGIN and Buddhayana is also too dominant, where all decisions must be in accordance with the agreement.

Against these criticisms, Suherman, the chairman of the West Java Indonesian Buddhist Council (Majelis Buddhayana Indonesia [MBI]), argued that the Buddhist scriptures were not only the Pali Tripitaka but also the Saddharma Pundarika text. In addition, the Pali Tripitaka itself is different. In the Pali Tripitaka Theravada in Burma the Milindapanha text is an integral part, while in the Pali Tripitaka the Sri Lanka and Thai Theravada schools are not.

Another Buddhayana follower, Cunda, stated that the socalled Buddhist scriptures did not come directly from the Buddha, but were a codification of the Buddha's teachings, which his disciples received orally. People do not know which teachings of the oral tradition came to Indonesia and from where. It should also be noted that a tradition that enters an area will adapt to the culture of that area. In addition, he also questioned which Theravada schools are pure because Theravada schools are also diverse and therefore people do not know which ones are pure and which are not. What is Sri Lankan Theravada? Burmese Theravada? Thai Theravada? In Thailand itself there are Mahanikaya and Dhammayutika Theravada schools, the question then arises as to 'which one is pure?'

Unlike Buddhayana and Theravada, Mahayana developed a view, which saw that the term 'Buddha' does not only refer to the historical Buddha (Siddhārtha, Sakyamuni Buddha) but also a spiritual principle. What appears, what is felt are only aspects of embodiment of the spiritual principle. Thus, if Theravada considers that Sakyamuni Buddha is an ordinary man who has succeeded in attaining Buddhahood in his life, then in Mahayana analysis, Sakyamuni Buddha is considered to have three types of bodies (trikaya), namely, nirmanakaya, sambhogakaya and dharmakaya.

Nirmanakaya is the physical body by which the Buddha was born and delivered his teachings. Because Nirmanakaya is material, this body in essence undergoes changes as it applies to other material objects. Sambhogakaya is a light body, which is the manifestation of a heavenly body. Dharmakaya is an essential body. As the dharmakaya spiritual principle exists by itself and is free from all duality and although it is said to be 'body', the dharmakaya is not person or is personal. As a person who has attained enlightenment Sakyamuni does not only say himself as 'Buddha' but he also often identifies himself as 'Tathagata', namely 'the one who has come' or 'the one who has gone' (Ling 1981). Therefore, dharmakaya is also called the Tathagatagarbha, literally means 'Rahim Tathagata'. In the context of this understanding Mahayana formulated the concept of Godhead.

In his article entitled 'Godhead in Mahayana Buddhism', Dutavira (1985) quoted the text of the Lankavatara Sutra:

Mahamati, if you say that there is no Tathagatagarba known as Alayavijnanam, then there is neither circumcision nor disappearance in His absence. The Tathagatagarba is also known as Alayavijnanam .... Mahamati, the Tathagatagarba (superior information) holds in both, namely: good and evil, and by Him all forms of circumstances are produced. (p. 190)

Although Buddhayana, Theravada and Mahayana differ in terms of the concept of God and the texts that become religious sources, they are the same in terms of belief in Siddhartha as the late Buddha. They also believe that one day the next Buddha will come, namely, Maitreya Buddha. This is different from NSI. According to the NSI, Nichiren is a person who has attained Buddhahood. Thus, Nichiren is a Buddha. Like Siddhartha, a prince who by his efforts attained enlightenment, so was Nichiren.

In addition, NSI explicitly states that the text of the Saddharma Pundarika Sutra is 'the most superior sutra' among other texts. In NSI's view, the superiority of a holy book does not lie in the thickness or thinness of a text or the originality and whether or not the language used in the holy book, but lies in the content or content contained in it. An NSI member unhesitatingly stated that the text of the Saddharma Pundarika Sutra is called the 'supreme sutra' because the Saddharma Pundarika Sutra contains a teaching, which says that everyone essentially has the seed or soul of the Buddha and that thus everyone, male or female, young or old, good or evil, can essentially attain Buddhahood or become Buddhas - not in the next life after death but in the present life. One of the NSI lecturers even stated emphatically that in order to achieve salvation, to attain Buddha's consciousness, one must follow the teachings of the Saddharma Pundarika Sutra because the Saddharma Pundarika Sutra is 'the only way, the only way, there is no other way'.

Nichiren Shoshu Indonesia's claim that the Saddharma Pundarika Sutra is the 'supreme sutra' means that NSI denies other texts that are part of the scriptures of other schools of thought, including Theravada, Mahayana and Buddhayana.

In terms of concept of God NSI relies on Nichiren doctrines. According to the Nichiren sect, the universe (the macrocosm) and human (microcosm) are one. That is, there are essential similarities between humans and the universe. The elements that make up humans are identical to the elements that make up the universe.

Furthermore, in explaining this human nature the NSI relies on the trikaya doctrine (three types of Buddha's body), a 
doctrine typical of Mahayana schools. According to Mahayana, the Buddha's body consists of three types: nirmanakaya, sambhogakaya and dharmakaya. Sangharakshita (1987) states that based on this trikaya teaching, the Buddha is considered not merely an ordinary human being but as the absolute reality itself. In order to convey the teachings of truth to all living beings, this absolute reality is manifested in various forms, including one of them in the form of Siddhārtha Gautama. Even though the form of Siddhārtha Gautama is real, it can be seen and touched, but the actual reality is transcendental. As ordinary Siddhārtha experienced birth and death, but the reality was not born and did not experience death. Siddhārtha Gautama was only an embodiment of absolute reality. The NSI then applies the concept of teaching to the analysis of the human body in general that the human body consists of nirmanakaya, sambhogakaya and dharmakaya. Nirmanakaya is a visible physical aspect; sambhogakaya is a moving aspect, such as thinking and feeling, while the dharmakaya is an energy aspect that unites the other two aspects.

The dharmakaya is also called Tathagatagarbha. Because the dharmakaya is not bound by space and time, it means that the dharmakaya exists by itself, is eternal and is everywhere and because Sakyamuni as the Buddha identifies himself with the Dharma, this means that the word 'Buddha' actually refers to the understanding of the Dharma, which is eternal and absolute. In other words, Sakyamuni itself is merely an embodiment of the absolute Buddhist principles.

Even though Nichiren refers to the doctrine of the tricks that are found in the Mahayana school, in the NSI the meaning of the dharmakaya undergoes expansion. In principle, both Mahayana and Nichiren both identify dharmakaya as the absolute principle, but in NSI, the dharmakaya is also understood literally, that is, dharma as 'teaching'. Speaking of dharma, all groups of Buddhist sects recognise that the dharma or teachings conveyed by the Buddha are basically built on the principle of causality (natural law or the law of cause and effect). However, in NSI the understanding of dharmakaya becomes more operational, which is understood as a regulating law. The implications of this expansion of understanding make a further difference between Mahayana and NSI. Even though both Mahayana and the NSI believe that in every human being there is a Buddha's seed or seed that is the aspect of the dharmakaya, the implications are different. Because Mahayana emphasises the dharmakaya aspect as the absolute principle, Mahayana religious orientation is speculative or, said one of the NSI followers, tends to be 'daydreaming', whereas in NSI dharmakaya it is understood as the principle of 'teaching', namely, the law of causality, and therefore the religious orientation of NSI tends to be practical and pragmatic, which is more directed to the reality and experience of everyday life. The Nichiren sect glorifies the Law, said an NSI administrator, while other sects glorify their people, such as Sakyamuni, Bodhisattva, Kwan Im and others.
It can be concluded that according to the Nichiren sect in man there are aspects of the dharmakaya or the dharma body, while the term 'dharma', which means 'teaching', is based on natural law or the law of cause and effect. The dharmakaya in the human self (microcosm) is the embodiment of the eternal and absolute Buddhist principles (macrocosm), while the eternal and absolute traits show the attributes of Godhead. Therefore, NSI formulates natural law or the law of cause and effect as a Godhead concept. Furthermore, the NSI says that the Godhead concept is identical to Nammyohorengekyo, as it was 'discovered' by Nichiren Buddha, and states that the Nammyohorengekyo mantra is also used as a greeting of respect.

In response to NSI's statements, Suyanto only questioned that if Nichiren is a Buddha, which Buddha is he? Because in the Theravada school there are Sāvakabuddha, Paccekabuddha and Sammāsambuddha. One Mahayana simply commented that 'Nichiren Buddhism is the Gohonzon religion', because on the altar of the Nichiren sect there is no Buddha statue but a Gohonzon. A Sāvakabuddha is a person who attains Buddhahood under the guidance of a teacher or other person. A Paccekabuddha is a person who by his own efforts attains Buddhahood, without a teacher or guide and does not impart any teachings to others. While Sammasambuddha is a person who attains Buddhahood by his own efforts and conveys teachings to others. Gohonzon is a sacred writing (mantra) made by Nichiren, which contains the laws of nature (cause and effect).

\section{Conclusion}

Not much response has been given to the theological views and beliefs of NSI, and this implies two possibilities. Firstly, other followers outside the Nichiren sect do not know about the theological doctrines of the Nichiren sect. Secondly, they realise that the potential for conflict in Buddhism is quite large, so they try to cover up the possibility of conflict. The issue of differences in scriptures that become the grip of each sect not only makes them different in religious practices but also provides various responses to sociopolitical problems that occur in Indonesia.

Furthermore, the absence of authority in Buddhism adds to the issue of these differences sooner or later, giving rise to hidden and open conflicts. In recent years, new sects came in and several new organisations emerged. In fact, at the national level a new organisation has emerged, which is called the Indonesian Buddhist Association (Permabudhi) after the establishment of the Indonesian Sangha Supreme Conference (Konferensi Agung Sangha Indonesian [KASI]). KASI and Permabudhi are both rivals for WALUBI as an organisation on behalf of Indonesian Buddhists.

The theological debates among Buddhist sects in Indonesia in this article only involve several sects. Perhaps it would be more interesting if further research could be carried out by involving other sects such as Maitreya, Tri Dharma and other sects. 


\section{Acknowledgements}

The author would like to express his gratitude to the followers of NSI, with whom he had impressive experience during field research, and Ke nsyu (retreat in Myoho Ji, central vihara of NSI). They were kindly willing to share their knowledge about their views of their beliefs and practices. The author would also like to express deep gratitude to members of Majlis Buddhayana Indonesia (MBI) in vihara Vimaladharma, Mahayana followers in Maha Vihara Lodan and members of Theravada sect in vihara Karuna Mukti, who openly answered his questions and shared their opinions within contextual understanding.

\section{Competing interests}

The author declares that they have no financial or personal relationships that may have inappropriately influenced them in writing this article.

\section{Author's contributions}

A.S. is the sole author of this research article.

\section{Ethical considerations}

This article followed all ethical standards for research without direct contact with human or animal subjects.

\section{Funding information}

This research did not receive a specific grant from any funding agency in the public, commercial or not-for-profit sector.

\section{Data availability}

Data sharing does not apply to this article as no new data were created or analysed in this study.

\section{Disclaimer}

The views and opinions expressed in this article are those of the author and do not necessarily reflect the official policy or position of any affiliated agency or the author.

\section{References}

Brown, I., 1987, 'Contemporary Indonesian Buddhism and Monotheism', Journal of SoutheastAsian Studies 18(1), 108-117. https://doi.org/10.1017/S0022463400001284

Brown, I., 2003, 'The revival of Buddhism in modern Indonesia', in M. Ramstedt (ed.) Hinduism in modern Indonesia: A minority religion between local, national, and global interests, pp. 57-67, Rutledge Curzon, New York, NY.

Conze, E., 1975, Buddhism: Its essence and development, Unwin Paperbacks, London.

Dhammaviriya, 1965, Ke Tuhanan dalam Agama Buddha [The Godhead in Buddhism], PUUl, Bogor.

Dharmavimala, 1995, 'Kata Pengantar' dalam Memahami Buddhayana ['Foreword' in Understanding Buddhayana], Yayasan Penerbit Karaniya, Bandung.

Dutavira, B., 1985, Pengantar Sejarah Agama Buddha Mahayana [Introduction to the history of Mahayana Buddhism], Lembaga Penerbit Pustaka Suci Mahayana, Jakarta.

Eliot, C., 1998, Hinduism and Buddhism: A historical sketch, Curzon Press, New York, NY.

Harvey, P., 1990, An introduction to Buddhism: Teachings, history and practices, Cambridge University Press, Cambridge.

Horner, I.B., 1959, 'Buddhism: the Theravada', in R.C. Zaehner (ed.), The concise encyclopaedia of living faiths, pp. 267-295, Beacon Press, Boston, CA.

Ishii, Y., 1984, 'Modern Buddhism in Indonesia', in G. Dhammapala et al. (eds.) Buddhist studies in honour of Hammalava Saddhatissa, pp. 108-115, University of Sri Jayawardenepura, Nugegoda.

Juangari, E., 1995, Menabur benih dharma di Nusantara: riwayat singkat Bhikkhu Ashin Jinarakkhita [Sowing the seeds of dharma in the archipelago: A brief history of Bhikkhu Ashin Jinarakkhita], Yayasan Penerbit Karaniya, Bandung.

Ling, T., 1981, A dictionary of Buddhism: Indian and South-East Asian, K.P. Bagchi, Calcutta.

Malalasekara, G.P., 1984, Encyclopaedia of Buddhism, The Cultural Publications Co. Ltd., Ceylon.

Rahula, W., 1985, What the Buddha taught, Gordon Fraser, London.

Sangharakshita, B., 1987, A survey of Buddhism: Its doctrines and methods through the ages, Tharpa Publications, London.

Smith, H., 1985, The religions of man, Harper \& Row, New York, NY.

Statistics Indonesia (BPS), 2010, Penduduk Menurut Wilayah dan Agama yang Dianut Indonesia [Population by Region and Religion Adhered to Indonesia], viewed 05 March 2015, from https://sp2010.bps.go.id/index.php/site/tabel?tid=321.

Suryadinata, L. (ed.), 1997, Ethnic Chinese as Southeast Asians, ISEAS Publishing, Singapore.

Suryadinata, L., Nurvidya Arifin, E. \& Ananta, A., 2003, Indonesia's population Ethnicity and religion in a changing political landscape, ISEAS Publishing, Singapore. 